\title{
ABOUT THE ARMY OF STATE OF JALOLIDDIN KHOREZMSHAH
}

\section{Negmatov B.M.}

Candidate Of Philosophical Sciences, Associate Professor Of Humanities, Academy Of The Armed Forces Of The Republic Of Uzbekistan

\section{ABSTRACT}

The article covers the army of Jalaliddin Khorezmshah state, its combat and mobilization status, forms and methods of warfare, the system of military officials, the tradition of selection of navkars, weapons, as well as military councils and their activities on the basis of sources.x

KEYWORDS:- State, army, guard, combat training, mobilization, battle, field battle, siege, alternative conflict, infantry, cavalry, flag, military councils, hunting, military officers, navkar selection, weapons, military inspection.

\section{INTRODUCTION}

It is known that the Khorezmshahs had a powerful army of their time and an excellent military system. When talking about the tradition of the Khorezmshahs to keep troops, first of all, it is worth noting that it resembles the palace and government organization of the Seljuks. Over time, a number of reforms were made in the armies. In particular, during the reign of Alouddin Muhammad, serious and effective work was done in the system of military officials, and during the reign of Jalaliddin Khorezmshah, on combat training.

According to the ancient tradition of the Turks, the army is divided into right and left wings. During the reign of the Khorezmshahs, the department of the Great Divan, the Divan, was in charge of military management. All records of funds received from the state treasury and their expenditures are kept in this office. Even in the time of Khorezmshahs there was a system of iqta. All the soldiers who served in the army had a certain amount of iqta. In particular, large and small commanders, commanders and military governors had rich talents. Large iqtaas could be reduced or enlarged, at the blessing of the ruler. The small iqtaas have not changed, they are considered otameros. As soon as the iqta owners were summoned, they gathered under the wing of their emirs, and when the march was over, they returned to their lands again. When the Khorezmshahs conquered a new land, the lands there were immediately divided into iqta, distributed among the officials, and the devon was recorded in the register of complaints. A huge cavalry force consisting of Iqta masters was stationed in different parts of the Khorezmshah state. They formed the soldiers of the province. 
CURRENT RESEARCH JOURNAL OF PEDAGOGICS 2(9): 13-18, September

2021 DOI: https://doi.org/10.37547/pedagogics-crjp-02-09-03

ISSN 2767-3278

(C)2021 Master Journals

\section{Crossref do) 11 Google}

Accepted 15th September, 2021 \& Published 20 ${ }^{\text {th }}$ September, 2021

There was also a guard of the ruler. Sultan Jalaliddin was undoubtedly the commander-inchief of the army. He commanded two great units that formed his army, both in peacetime and during the march: the Guards and the provincial troops. The minister commanded and conquered the armies of Khorezmshah in Azerbaijan and Arron. Jalaliddin Khorezmshah, in turn, was always at the head of the army. Although he occasionally mobilized this or that emir to conquer any region, he soon caught up with him and took command.

The Khorezmshahs, in addition to the permanent units, had a guard (haras) consisting of slaves who had been bought or taken prisoner as a result of the war. Such a guard was first formed by Khorezmshah Alouddin Takash. The palace emirs, who had certain duties and powers in the organization of the palace, commanded the guard. Khorezmshah Alouddin Muhammad had 10,000 men in his ranks ${ }^{1}$. In addition to guarding Khorezmshah and his family, the guard was used to accompany various expeditions, trade caravans.

For example, during the reign of the Khorezmshahs, the Guards were located in and around the capital and were under the direct command of the sultan. In the time of Jalaliddin, this army was always with the sultan. The sultan had to be on different sides of his country, handing over the defense of the province of Azerbaijan to the minister. Consequently, the guard was always on the move, with the sultan. The so-called "private slave" unit selected from the Guards was tasked with protecting the sultan's safety and life. During the war, this part was around the sultan.

According to historical sources, during the reign

${ }^{1}$ Зиё Бунёдов. Марказий Осиёга доир тадқиқотлар. Хоразмшохлар-ануштегинлар давлати. - T.: MUMTOZ SO`Z, 2012, 126-бет. of Khorezmshahs there were enough military units in the regional centers. In addition, there were defensive parts in the country's frontier parts, roads, and fortified castles of defensive importance. The governors and castle commanders were appointed mainly from palace servants of Turkish origin. Later, they were appointed from among the great seed princes. Under the hands of these wealthy and influential individuals were also private military units that were directly subordinate to them and in most cases consisted of slaves. Seed beys took an important part of their seed to the place of service. The local units, consisting of the iqta owners, were also under their control. When necessary, the army also recruited mercenaries from the people. Called the Hashar, this volunteer unit was mostly used in the defense of the city and the castle. The military units called "Hasham" and "Mutanajjida" formed the basis of the army ${ }^{2}$.

It is known that during the reign of Sultan Alouddin, the army consisted first of Kipchaks, then of kalach, qarluq, uranium, uraq. The mercenary Kipchak-Kangli, under the command of the tribal chiefs, formed the basis of the guard. Some Kipchak beys revolted against Jalaliddin after his appointment as caliph and even caused Jalaliddin to leave the capital. That is why Sultan Jalaliddin did not trust the Kipchaks until the end of his reign and did not enlist them in the army. The Kipchaks, too, looked at him fearfully and hesitated to enter his arms. It was only in the last years of his reign that the threat of the Mongols increased that Sultan Jalaliddin used Kipchaks, according to sources. The details of the following incident are clear evidence of this. In 1228 (626), Sultan Jalaliddin was defeated by the Mongols in Isfahan and fled to Ajam, Iraq. On his way back to Tabriz, he sent one of the Kipchak officials to the

${ }^{2}$ Тонарий О. Жалолиддин Хоразмшох ва унинг даври. - Т.: Шарқ, 1999, 89-бет. 
CURRENT RESEARCH JOURNAL OF PEDAGOGICS 2(9): 13-18, September

2021 DOI: https://doi.org/10.37547/pedagogics-crjp-02-09-03

ISSN 2767-3278

(C)2021 Master Journals

\section{Crossref do) 11 Google}

Accepted 15th September, 2021 \& Published 20 ${ }^{\text {th }}$ September, 2021

Kipchaks to carry out his plan. The Kipchaks first accepted his offer and sent a section of fifty thousand tents near Darband. Kurqa, one of the chiefs of the Kipchak clan, went with three hundred men to Sharafulmulk, who was stationed in Muqan. Sultan Jalaliddin came to Muqan in the spring of the following year and received Qurqa. Kurka promised to enter the service of the sultan. The Sultan dressed Khurqa and his benefactors ${ }^{3}$.

During the reign of Sultan Jalaliddin, some parts of the regional army consisted of Turkmens. Turkmens lived in the western part of the country, in an area that stretched from Arron to Jibal. The Turkmens played a major role in the army of Sultan Jalaliddin and made a huge contribution to important victories. In the last years of his reign, he told his personal secretary, Shihabiddin al-Nasavi, "The Turks (Turkmens) and the commanders of my army have shown selflessness, even if they do things they do not want to do." Indeed, the Turkmen remained loyal to the sultan until the last minute. In early 1231, at a time when the Mongol threat was at its height, he sent Jalaliddin Nasavi to invite the Turkmen. Even at such a critical time, the Turkmen khans joined the sultan's weak army ${ }^{4}$.

Khorezmshah Jaloliddin gave high ranks to the commanders of the army. He, like his father, Sultan Alouddin Muhammad, gave the titles of khan and malik, higher than the rank of emirate, to higher officials. At that time, the khan was considered the highest rank of the army. He was followed by Malik and Amir. Then in the army there was a category of high-ranking navkars called "sipoh-bud" and who commanded the cavalry. The commander of the avant-garde unit

${ }^{3}$ Тонарий О. Жалолиддин Хоразмшох ва унинг даври. - Т.: Шарқ, 1999. - Б. 89-90.

${ }^{4}$ Ўша жойда, 90-бет. was called a "hero." Under the leadership of highranking khans, maliks, amirs, sipoh-buds, and warriors, there were small-ranking navkars, sarhans, and sergeants.

When Sultan Jalaliddin left Abiskin for Khorezm after his appointment as Wali'ah, he was accompanied by only seventy people. In Gurganch, his navkars reached seven thousand at the expense of most boyagut seeds. However, Jaloliddin was forced to leave the capital and go to Khorasan as a result of the betrayal of his brothers, who fought for the throne and entered the path of conspiracy. There were only three hundred men with him at that time. From here, Jalaliddin, who had marched to the Treasury, summoned Amin Malik, the son of Jalaliddin's uncle, with ten thousand cavalry, and they joined Jalaliddin. Sayfiddin Bugrak and other emirs, originally from the Qalach clan, joined the treasury with a total of 30,000 men. In turn, Jalaliddin and Amin Malik also had 30,000 navkars. Thus the number of troops reached 60,000 . It was only a short time later that the castles lost Jalaliddin. The sources cite the following details of the incident as the reason for this, i.e. the spoils were distributed after a victory of Sultan Jalaliddin over the Mongols. Amin Malik then beat Sayfiddin Bugrak with a whip for plunder. As a result, the qalachis abandoned Jalaliddin's army.

For example, in the battle on the banks of the Indus River, Jalaliddin had an army of 30,000 men. When Sultan Jalaliddin left for India, he was accompanied by only 4,300 Khorezm navkars, several of whom were wounded. This army was joined by refugee and refugee Indians in India, and the number of navkars reached ten thousand. Deciding to return to Iran, Jalaliddin left some of his navkars in India. Khorezmshah Jaloliddin entered Kirman with four thousand navkars riding oxen and mules. It is known that when Sultan Jalaliddin Barak went to Kerman to punish Hajib, he had 11,000 navkars. 
CURRENT RESEARCH JOURNAL OF PEDAGOGICS 2(9): 13-18, September

2021 DOI: https://doi.org/10.37547/pedagogics-crjp-02-09-03

ISSN 2767-3278

(C)2021 Master Journals

\section{Crossref do) 11 Google}

Accepted 15th September, 2021 \& Published 20 ${ }^{\text {th }}$ September, 2021

So, it is difficult to say the exact number of the army of Khorezmshahs in the time of Jalaliddin. The reason is that the number of his army is recorded differently by historians in different sources. Summarizing the information in the sources, it can be said that the number of Sultan Jalaliddin's army did not exceed 50,000.

The flag of Sultan Jalaliddin was black. The Khorezmshahs belonged to the Bekdili clan of the Oguzs. It is natural, therefore, that their black flag bears the seal of this tribe, and that the names and nicknames of the sultan are inscribed. During a journey, journey, or war, the flag of the ruler was carried by the flag bearer or by several flag bearers. Sultan Jalaliddin paid special attention to the flag, which was the symbol of his family and himself. During a battle with the Mongols near Isfahan, one of the flag bearers around him fled in fear. Then the sultan immediately chases him and kills him with a spear blow.

According to sources, in those days it was customary to present a flag to a member of the ruling dynasty of the class. Giving the flag in such cases signified that the dynasty and the people had united to fight the oil. Indeed, it is known that after the death of Sultan Alouddin, the Crown Prince Jaloliddin and his brothers, who left Abiskin for Khorezm, were given flags along with horses and weapons.

Parts of the Khorezmshah's army also carried a black flag, a symbol of the state. By the way, Khorezmshahs had their own flags of great emirs, ie khans, Maliks and amirs, chiefs of clans.

It is known that horses played an important role in the life of any army. Given that the army consisted mainly of cavalry, then the importance of the horse becomes self-evident. Sultan Jalaliddin attached great importance to the horse. He had thrown himself into the Sind River on horseback, and with the help of his horse had crossed to the other side and escaped death. He kept this horse for many years. When the issue of sending gifts to the caliph was raised, the sultan ordered the selection of Mongol horses. It should be noted that the sultan and officials raised horses on special pastures.

The army was also supplied at the expense of horses purchased from the nomadic Turkmens and taken as booty. It is also known that vassal rulers sent horses, mules, and camels as gifts. For example, among the gifts that Alouddin sent to the envoys of Qayyubad and Sultan Jalaliddin were 100 horses and 50 mules.

Both cavalry and infantry navkars of Khorezmshahs were armed with advanced weapons of their time. In addition to the usual weapons of war - swords, spears, arrows, bows and daggers, the armies of the Khorezm kings were palahmons (manjanik), siege machines (dabbabat), "turtles", ie walking towers (mataris), wall-breaking devices (jamaluq) and during the attack. those who have used ladders (salalim) ${ }^{5}$. Khorezm navkars also wore armor. They had black ears on their heads.

Sultan Jalaliddin also paid great attention to the issues of combat training of the army. In particular, the mobilization was undoubtedly announced only by the sultan. Given the existence of a council institution, it can be concluded that the mobilization was announced after the council.

When Jalaliddin Khorezmshah decided to mobilize, he fired red shots at high-ranking commanders of the army, ie khans, Maliks, amirs and warriors, and sometimes at sergeants. The commander of the unit, which had received the red arrow, immediately approached the sultan with his navkars under his command.

${ }^{5}$ Буниёдов 3. Ануштагин Хоразмшохлар давлати (1097-1231). - Т.: Ғафур Ғулом номидаги Адабиёт ва санъат нашр., 1998, 122-бет. 
CURRENT RESEARCH JOURNAL OF PEDAGOGICS 2(9): 13-18, September

2021 DOI: https://doi.org/10.37547/pedagogics-crjp-02-09-03

ISSN 2767-3278

(C)2021 Master Journals

\section{Crossref do) 11 Google}

Accepted 15th September, 2021 \& Published 20 ${ }^{\text {th }}$ September, 2021

There was another form of mobilization. Sultan Jalaliddin sent a letter to his commanders summoning them. Apparently, when the communication with the army commanders was somewhat diminished, the sultan used the method of summoning them to convince them.

When Sultan Jalaliddin returned from India, he ordered his brother Giyasiddin Pirshah to obey and sent rings from an envoy to his emirs. Some emirs take the ring and go to Jalaliddin's side. Others hand over the ring to Giyosiddin to show their support. The method of sending a ring is an attempt to obey. However, there is no information in the sources as to whether or not the sultan sent a ring to his emirs to take the necessary measures in case of external danger.

When Jalaliddin Khorezmshah decided to go to war, he organized a hunt a day or two before the clash with the enemy. This hunt is essentially a military maneuver, and the tactics used during the battle have been tested. Sultan Jalaliddin also conducted an official inspection of the army before the battle. In this way the sultan controlled the training of the soldiers and their equipment. The official parade also served to lift the spirits of the soldiers.

Military councils played a special role in the Khorezmshah state. The assembly, chaired by the sultan himself, was attended by the khans, princes, and emirs who went to war. At the meeting, a decision was made on the tactics to be used in combat. Since the final verdict applied to the sultan, the decisions of the military council were of a recommendatory nature. For example, before a battle with the Georgians, Sultan Jalaliddin convenes a military council with the participation of his minister and commanders. The minister proposes to postpone the battle because the enemy troops are outnumbered. Outraged by this proposal, the sultan struck the minister on the head with a dawat (ink) and announced his decision to fight ${ }^{6}$. However, sources say that Sultan Jalaliddin relied on astrologers' information on which day to start the battle.

The battles carried out by the Khorezmshah army were mainly in the form of field battles, sieges and alternative clashes. An alternative confrontation is a smaller-scale field battle.

In battle and alternative battles, Sultan Jalaliddin lined up his army in the traditional way, that is, on the right, center, and left flanks. The center was commanded by him himself. The center usually consisted of Guards troops. The right and left wings were commanded by khans, kings and emirs. The right and left wings were in any case composed of provincial armies. In most cases, the center consisted of cavalry, the right wing archers, and the left wing infantry. During the battle, they fought in the front line with a typical slave around the sultan. The Khorezmians and the Mongols, who were bone enemies with each other, did not accept each other's fighting style. Khorezmshah's troops fought on the basis of traditional order and tactics. The Mongols, on the other hand, fought their units in two rows in their own special fighting style.

Sultan Jalaliddin ambushed both in field battles and in alternative battles. For example, in a battle with the Caliph's army under Kushtemur's command, Jalaliddin allegedly fled after several attacks, and the enemy chased him away. As a result, the enemy was ambushed ${ }^{7}$. It should be noted that Jaloliddin also ambushed in the battles with the Mongols.

\footnotetext{
${ }^{6}$ Шихобиддин Мухаммад ан-Насавий. Султон Жалолиддин Мангуберди хаёти. - Т.: O'zbekiston, 2006. - Б. 138-139.

${ }^{7}$ Шихобиддин Мухаммад ан-Насавий. Султон Жалолиддин Мангуберди хаёти. - Т.: O‘zbekiston, 2006. - Б. 138-139.
} 
CURRENT RESEARCH JOURNAL OF PEDAGOGICS 2(9): 13-18, September

2021 DOI: https://doi.org/10.37547/pedagogics-crjp-02-09-03

ISSN 2767-3278

(C)2021 Master Journals

\section{Crossref do) 11 Google}

Accepted 15th September, 2021 \& Published 20 ${ }^{\text {th }}$ September, 2021

Sultan Jalaliddin used the invasive form of war more in India. The low number of navkars must have played a role in this. The sultan, confronted by the enemy army, studied the strength of the enemy, what forces his army consisted of, and tried to dismantle this power through diplomatic means. For example, when he learned that in one of the battles with the Georgians there were kipchaks in the ranks of the enemy, the sultan sent them bread and salt. As a result, the kipchaks left the battlefield ${ }^{8}$.

During the siege, Khorezmshah Jaloliddin used maneuvers, sledgehammers and oil. As the siege lasted a long time, the sultan placed his troops in a circle around the castle, building houses around the city. Sources say that Sultan Jalaliddin also used tricks to deceive his enemies. For example, it is known that he left Isfahan for Ray with a white flag resembling the flag of the Mongols.

After each victory achieved by the armies of the Khorezmshahs, a conquest was written to make friends happy, to make enemies cry and to retreat. The conquest was written by munshis (secretaries) and sealed with the sultan's flag. The conquest was handed over by high-ranking officials. After the conquest of Hilat, a conquest was written by Shihabiddin al-Nasavi, the sultan's munshi. Written in a classical style, this conquest begins with praise to Allah and then states: "We have once again shown our strength to our enemies. They realized they had made a mistake. We forgave them for being good. Mujiriddin and Taqiyuddin, the brothers of Izziddin Oybek and Malik Ashraf, as well as the high ranks of the Ayyubids, promised to serve us. We have forgiven them" ${ }^{\prime 9}$.

${ }^{8}$ Ўша жойда, 215-217-бетлар.

${ }^{9}$ Шихобиддин Мухаммад ан-Насавий. Султон Жалолиддин Мангуберди хаёти. - Т.: O'zbekiston, 2006. - Б. 233-244.
Thus, the army of Khorezmshah Jaloliddin in his time showed great zeal in the defense of the Motherland, ensuring the prosperity of the country. The rich military skills and experience left over from it serve as an important source in the formation and strengthening of a professional army in our country today, increasing the combat readiness of servicemen, instilling in them such qualities as patriotism, devotion, perseverance and determination.

\section{ReFERENCES}

1. Зиё Бунёдов. Марказий Осиёга доир тадқиқотлар. Хоразмшохларануштегинлар давлати. - T.: MUMTOZ SO'Z, 2012. - 372 б.

2. Тонарий О. Жалолиддин Хоразмшох ва унинг даври. - Т.: Шарқ, 1999. - 128 б.

3. Буниёдов 3. Ануштагин Хоразмшохлар давлати (1097-1231). - Т.: Ғафур Ғулом номидаги Адабиёт ва санъат нашр., 1998. -256 б.

4. Шихобиддин Мухаммад ан-Насавий. Султон Жалолиддин Мангуберди хаёти. T.: O'zbekiston, 2006. - 384 б.

5. Tashpulatovna T. A. The role of the older generation in protecting the modern youth from social dangers //European Journal of Molecular \& Clinical Medicine. - 2020. - T. 7. - №. 7. - C. 971-981.

6. Tashpulatovna T. A. The role of the older generation in protecting the modern youth from social dangers //European Journal of Molecular \& Clinical Medicine. - 2020. - T. 7. - №. 7. - C. 971-981. 